\title{
MORPHOLOGICAL AND PHONOLOGICAL VARYING SYSTEM OF GORONTALO LANGUAGE AND THE PROBLEM OF ORGANIZING THEM IN CUSTOM TERMS DICTIONARY
}

\author{
Kartin Lihawa, Rasuna Thalib, Agus Lahinta dan Adimawati Helingo
}

\author{
Universitas Negeri Gorontalo
}

\begin{abstract}
The objective of this research is to describe the morphological and phonological varying system of Gorontalo language, and its problem in organizing them in custom terms dictionary. The method used is qualitative with the data collection techniques involved observing, recording the language in a practical poem of the traditional ceremony, and other published books. The agreement of wordwriting problems through workshop alignment and standardization are (1) deletion of sound $\boldsymbol{y}$ and $\boldsymbol{w}$ in certain words, (2) there is no unique phonetic symbols of apostrophe for glottal sound between two sequence vowels written side by side in a row, (3) selection of writing $n t$ for the sound /ð/, (4) selection of particles mayi, mota, mola, mao, ma, ngo, o (for verb not for noun), hi, lo, de, dipo, ta, (5) selection of prefix po attached to the verbs, (6) variations of long and short vowels writing on certain phonemes.
\end{abstract}

Keywords: morphology, phonology, varying system, Gorontalo language, organizing custom terms dictionary, non-standardization.

\begin{abstract}
Abstrak: Tujuan penelitian ini adalah mendeskripsikan sistem variasi morfologi dan fonologi Bahasa Gorontalo serta masalah pengorganisasionnya dalam kamus istilah adat Gorontalo. Penelitian ini menggunakan metode kualitatif dengan teknik observasi, perekaman bahasa puisi praktis pada acara tradisional meliputi kata, farse, kalimat, termasuk buku-buku terbitan. Persetujuan mengenai masalah penulisan kata melalui penyelarasan pada workshop dan kesepakatan standarisasi antara lain 1) pelepasan bunyi $\boldsymbol{y}$ dan $\boldsymbol{w}$ pada kata-kata tertentu, (2) tidak ada simbol fonetik khusus apostrof untuk bunyi glotal di antara tulisan dua deretan vokal, (3) pemilihan penulisan $n t$ untuk bunyi /ठ/, (4) pemilihan pemisahan partikel mayi, mota, mola, ma'o, ma, ngo, o (untuk kata kerja, bukan kata benda), hi, lo, de, dipo, ta, pada salah satu kata tertentu. (5) pemilihan melekatnya prefix po pada kata kerja, (6) variasi penulisan vocal panjang dan vocal pendek pada fonem tertentu.
\end{abstract}

Kata Kunci: morfologi, fonologi, sistem variasi, Bahasa Gorontalo, Penyusunan kamus istilah, non-standard 
Every language in the world has its own rules of word form. Based on its rules, a word in a certain language can change to some classes of the words, which is known as parts of speech. A noun can be a verb, an adverb, and an adjective. This varying is considered as a complex rule that needs to be analyzed. As the example in English, it can be found words such as comfort $(\mathrm{N})$ can be comforter $(\mathrm{N})$, comfortable (Adj.), comfortableness $(\mathrm{N})$, uncomfortable (Adj.), and comforted (V). When it is classified by its rules of word form, this word has complex affixation, and these rules are in studying area of morphology. Akbulut (2017, p. 12) illustrates that morphemes which incorporate roots, stem, prefixes, and suffixes, are the smallest parts of words that convey significance.

Lardiere (2006, p. 66-67) provides examples in English, such as interpretability which consists of the root lexeme interprete, a prefix -un, the suffix -able, and-ity. This is the most common morphological process for modifying the root which is by adding those prefix -un and the two suffixes (-able and -ity). It is also stated that most of the world languages use some kinds of suffixing to indicate grammatical information about a word or its relation to other words.

Gorontalo language is one of the local languages in the northern part of Sulawesi Island, Indonesia. This language has a common morphological process as the others. It has a complex structure words. However, this language is still far from its standardization of writing words from either morphologically or phonologically. It has varying system of writing words form. This has become the issue of the language.

The issue of morphological analysis automatically may affect the system of writing phonetic symbol. Moreover, when we organize a dictionary, it is more challenging to determine than to write word form. Because of the problem, the organization of dictionary is in less alphabetically system of lexeme roots or words.

Affixes are considered in organizing problem of the dictionary. Lardiere (2006, p.67) states that an affix is a grammatical morpheme which (by definition) must be bound to a root as to another affix. Any form of an affix attaches to, whether simple or complex, is called a base (or a stem). Affixes which attach to the right, or end, of a basis, are called suffix. Affixes which attach to the left, or front, of a base are called prefixes.

The affixes in Gorontalo language as the issues of the different writing form of words are found from the traditional poems which were applied in its practicing in traditional ceremony apart from in its documents; others are from scientific writing written by some experts in the area.

Those problems of varying writing words form are dominated by six points of different writing in: (i) variations of the use of vowels to be consonant, (ii) variations of changing between the vocal and vocal changes to the consonant, (iii) differences in writing $n t, n d$, $n t h$, and $n t h$ in certain words of Gorontalo language, i.e hulonthalo, hulondalo, hulonthalo, hulondhalo, (iv) the stems attached and not attached to a word which refer to adverbial of place included the use of to. Those stems are maqo, mota, mola, mayi (demowamaqodemowa maqo 'take it there'; far from here', demowamota - delowa mota 'take it there; near from here', demowamayi - delowa mayi 'take it here', demowamola - delowa mola 'take it there; far to the levels of the top or higher', and to 'refers to', (v) differences in using / writing long and short vowels, (vi) the variation in writing word forms which contain infixes.

Those six points are the problems which refer to the non-standardization of Gorontalo language and some influence to the problem of ambiguity in determining the meaning of certain words, besides those may affect to decide what standard of writing phonetically can 
be chosen in the dictionary. In the opposite side, the dictionary that will be made is a standard custom term dictionary.

The information of Gorontalo language non-standardization of word formation rules is described in this study. The result of the solution of conducting workshop program is going to generate a policy for the people and the government agreement on the use of standardizing this language.

\section{THEORETICAL BASES}

\section{Morphemes and Phonemes}

Describing morpheme in a language is not avoiding from word form. Words are the basis of analysing morpheme. It is stated in Linguistics 051 Proto-Indo-European Language and Society Introduction to Morphology that morphemes are the smallest units in the structural analysis of words.

The words analysis is started from the demanding simple word or stem. It usually can be complex, because of the rules of language grammar naturally. (Roach, 2000, p. 104) The words that were described were called 'simple' words; simple words in this context means 'not composed of more than one grammatical unit', so the word 'care' is simple while 'careful' and 'careless' (being composed of two grammatical units each) are complex, 'carefully and 'carelessness' are also complex and are composed of three grammatical units each. This Roach's idea refers to a word is as a word can be one morpheme or more. Besides that one word also can be a stem. In Crystal's Dictionary (1985) stem is a term often used in linguistics as part of the classification of the kind elements operating within the structure of a word. The stem may consist solely of a single root of morpheme (i.e. a 'simple' stem as in man), or of two morphemes (i.e. a 'compound' stem, as in blackbird), or of a root morpheme plus a Derivational Affix (i.e. a 'complex' stem, as in manly, unmanly, manliness). All of these have in common is that it is the stem that inflectional affixes are attached.

Morpheme consists of bound morpheme and free morpheme. Both of them are studied in the grammatical rule of words.

\section{Homonym and Phoneme}

Lardiere (2006, p.56) gives definition and example of word phonology does play important role across languages in identifying the boundaries between words. It is given an example below of the string of /grinhaus/ which is stated phonological stress this ambiguities meaning of the utterances in (1a) and (1b), indicating that /grinhaus/ is single (compound) word in (1a) but two distinct words in (1b). Phonology can help us identify words, but we need other information as well. Examples:

- Tea's good for you.

- That shop sells teas from around the world.

- I asked him not to tease the cat.

The tea's in $a$ is the contracted form of the word, but it is phonetically identical to that of teas in $b$ and tease in $c$, all are pronounced /tiz/.

Those different forms of the words with similar pronunciation or the same sounds are included in the term of homonym. Ulman (2007, p.223) states the most common occurrence 
of homonyms is through convergence and fusion of sounds. Because of the effect of the sound, two or three words that were originally different in shape were then converted into one sound in an oral language or sometimes up to the writing. The process is simple, which can be illustrated below.

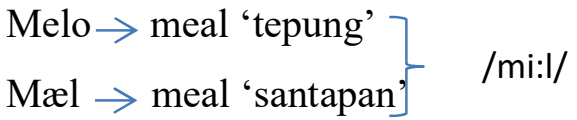

$$
\begin{aligned}
& \left.\begin{array}{l}
\text { Mête } \rightarrow \text { meat 'daging' } \\
\text { Mêton } \rightarrow \text { meet 'bertemu' } \\
\text { Metan } \rightarrow \text { mete 'membagi }
\end{array}\right\} \quad \text { /mi:t/ }
\end{aligned}
$$

Another examples of homonym in Indonesian language given by Chaer $(2009$, p.94) are the words ${ }^{1}$ bisa and ${ }^{2}$ bisa. When ${ }^{1}$ bisa is 'snake poison', it has homonym with ${ }^{2}$ bisa is as 'can' or 'is/are able'. Verhaar (in Chaer, 2009, p.94) gives definition of homonym is the idiom in terms of word, phrase, or sentence which those form are the same with others as they are words, phrases, or sentences, but its meaning are different. It is emphasized (Djayasudarma, 2008, p.43) that "homonym is the symptoms of the same written and pronounces of two words". The two words here are in different meaning.

This homonym has also happened in Gorontalo local language in North Sulawesi, dila /'di:la/ 'no', dila /'dila/ 'tongue', and dila /'di:la/ 'kiss'. These facts are actually happened in the daily life of Gorontalo people in applying their practicing the speech poems in a traditional ceremony, and particularly in linguistic experts and language and literacy's scientific writing. This is based on Foley's discussion about linguistic research in 2002 in Springer that "the ideal way to study the language of a traditional community is in the situation, living with the village, learning as much of the social customs of the people as possible".

In organizing these words in dictionary Chaer (2009, p.94) emphasized that the words which have homonym are usually coded by Roman numerals are placed behind each word (entry) which has its homonym with it: or also with Arabic numerals raised a half space and placed in front of the word, i.e. ${ }^{1}$ bisa and ${ }^{2}$ bisa or bisaI and bisaII. So in the Gorontalo language dictionary, the word 'dila' and 'hulango' which have homonym can also be written in Roman numerals or Arabic numerals.

\section{THE PROBLEM OF ORGANIZING}

\section{Dictionary}

In organizing dictionary, the organizer must have the purpose to which the dictionary is intended to. (Chaer, 2007, p. 212) states that if the dictionary intended to the language speaker itself, then it should be a dictionary monolingual. If the dictionary is intended for people who are not the language speaker, it is then must be compiled as a bilingual dictionary.

According to Chaer (2007, p.214), the corpus of data is recorded by the speakers of the language and transcribed in the written form of the phonetic spelling language to orthographic spelling forms to determine the language phonemes in their graphemes. If the source language dictionaries already have been in written form, then the corpus is taken from manuscripts, books, newspapers, magazines, and other publications. 
On the contrary, the preparation of Gorontalo language custom terms dictionary begins with the recording data source from the field and then followed by the workshop program which agreed on writing a number of words that have not been standardized.

Furthermore, Chaer $(2007$, p.215) states the mistake of taking the corpus will cause the dictionary being compiled not reaching the target, or the other word becomes useless.

In order to be useful, the word corpus custom term dictionary in Gorontalo language taken from all practical data in the field. Because of the custom terms are the height level of using language, those terms are unusual used in societies' daily communication, that the terms are put inside from the people's life. Thus, there are many terms that are difficult to understand whenever those sounded in a practical formal traditional speech poem. One of the efforts is to put terms in an e-dictionary in the form of a web. This dictionary is not only the language users who know the language of customary language but even outsiders with the goal of maintaining Gorontalo local language as well as the introduction of the culture. According to the Chaer (2007, ch.215), the data dictionary must be taken from the language corpus should be still in use.

The main problem in organizing dictionary, including 1) deciding objective of composing dictionary, 2) data corpus, and 3) its collecting data. There are three later points: 1) organizing entries and sub-entries which consist of 9 sub-points those are a) basic form as stem of Indonesia 'juang' which never used in speech in terms without giving previous morphological process on the form of the word, b) the order of sub-entries, the root which followed by others which have morphological process of grammatical affixation, c) gradual affixes on word; i.c. agree - agreement - interested, d) space of recurring words (only in Indonesian), e) compound; this should be placed partly in dictionary, f) the place of nonstandard words, g) the space of foreign word: borrowing words are listed as entries and describe the meaning clearly, $h$ ) the space of abbreviation and acronym can be put in dictionary and placed in certain space because there is no rule of this, i) proverb space; it can be placed below the entries which belong the proverb. 2) meaning problem is clearly and completely covered, and 3) information labeling.

\section{METHOD}

The data of this study were obtained from the draft of custom term Gorontalo language dictionary which have been collected previously through recording language data in practically poem of traditional ceremony which is covering words, phrase, sentence, and other published books from dissertation and other research findings. Those data were helped by the linguistic computation program with the process of storing the language data in true base screen. This true base is organized by Kemeny and Thomas, E. Kurtz (1985). It focuses on storing language data in computer program that result the language in alphabetically form. The data in custom term Gorontalo language dictionary were analyzed qualitatively by the techniques of classifying varying writing morphological and phonological words form.

\section{FINDING AND DISCUSSION}

\section{Finding}

In line with gathering the data in custom term dictionary, there were two points found i) morphological and phonological varying system of Gorontalo language, e.g. the word 
lentongo 'stopped' can be (-e-ee) lentongo - le entongo, (-o-oo) lentoongo - leetoongo, (-t$\underline{\text { th}}$ - $\underline{\text { d-dh}}$ ) lenthongo - lenthoongo- lendongo - lendoongo-lendhongo -lendhoongo. It also can be (-e -ee) leenthongo - leenthoongo - leendongo-leendoongo - leendhongo - leeendhoongo.

Based on this finding, this word has 16 varying writing forms. ii) Because of the varying system of non-standardization of Gorontalo language, there are the problems of organizing words in the dictionary. These problems are (i) repeating the same term in different space in the dictionary (ii) there are two possible definitions of one word or term which may effect of making different formulation or description of sentences in defining the same term.

\section{Discussion}

\section{Gorontalo language Morphological Problem}

This section discusses the morphological and phonological varying system of Gorontalo language which can be categorized as a non-standardized language. It is realized by the speaker of the language user of Gorontalo societies that their language has still a varying system of writing words form. The varying system which was found from the process of organizing dictionary is as follows:

\section{Morphological and Phonological Varying System of Gorontalo language}

1) The variation of the use of vowel to be consonant

$$
\begin{aligned}
& \text {-a - ya amiatia - amiyatiya } \\
& \text { amiatiya - amiyatia 'we.' } \\
& \text { utia - utiya 'this.' } \\
& \text { loiya-loqia - loqiya } \\
& \text { lo'ia- lo'iya - lo?ia } \\
& \text { lo?iya 'speech' } \\
& \text {-a-wa moali-mowali 'can be' } \\
& \text { Pohutua-pohutuwa'do that.' } \\
& \text {-o - wo toduolo - toduwolo } \\
& \text { maa toduwolo } \\
& \text { matoduwolo } \\
& \text { maa toduolo } \\
& \text { matoduolo } \\
& \text { matoduwolo 'welcome.' } \\
& \text { hilao-hilawo 'heart; wish.' } \\
& \text { - u -w u wau- wawu 'and' consider }
\end{aligned}
$$


14 | BAHASA DAN SENI, Tahun 46, Nomor 1, Februari 2018
wau or wa'u 'I'
ta $\boldsymbol{u}$-tawu'people' consider
ta $\boldsymbol{u}$-ta' $\boldsymbol{u}$ 'above; over.'
ouhua- owuhuwa-owuhua
'expelled'
-u - wa bua buwa 'girl; woman' consider

bu $\boldsymbol{a}$ or bu' $\boldsymbol{a}$ 'crack.'

-o-yo liodu - liyodu 'step.'

tiombu - tiyombu 'grand

mother/father.'

2) The Variation Changing of The Vowels

$-\mathrm{a}-\mathrm{u} \quad$ bangu - bongo 'build'

momangu bele or Momongu

bele 'to build a house'

bangu-mobangu 'call to prayer'.

-u - o humulo - humolo in Bulentiti humulo -Bulentiti humolo 'the exalted bride."

-a - ya hunggia-hunggiya 'country; land.'

sadia - sadiya 'ready.'

$-\mathrm{i}-\mathrm{yi} \quad$ tinggai- tinggayi

tingge - tinggeyi 'same

function; rival; people equal'.

- mo -ngo tapohumo - topohungo - tapahungo

tapohumo lulungo or topohungo lulungo 'corpse carried'.

-wawu - wewu is the stem

otutuwawu lo Allah or

otutuwewu lo Allah 'the only one of Allah'

$-\mathrm{y}-\mathrm{w} \quad$ uito-uyito-uwito 'that is'

\section{Varying System of Writing Words Contain Letters nt, nd, nth, and ndh}

- hulontalo-hulondalo-hulonthalo-hulondhalo 'Gorontalo language'

- Pohuntala - pohundala - pohunthala - pohundhala 
'serving delivery'

- Huntingo - hundingo - hunthingo - hundhingo 'cutting; scissor'

- Ilohuntuwa - Ilohunduwa - Ilohunthuwa - Ilohundhuwa

'a gathering place'

- Huhuntula - Huhundula - Huhunthula - Huhundhula

'employees; the welcome guests'

- Pontolo - pondolo - pontholo - pondholo 'border'

- Pohintu - pohindu - pohinthu-pohindhu

'ask to permission; agreement'

The stems Attached and Not Attached to A Word (Included Prefix to and The Words mao;maqo, mota, mola, mayi;mai)

- to Todala - to dala ' on the street'

Topomama - to pomama

'in place of a set of siri tools'.

- to tahuwa-totahuwa, to tahua 'in a storage'

- to ta dadata-totaadadata-to taadadata - daadaata-to ta daadaata

$\underline{\text { to ta } \mathrm{d}} \mathrm{\textrm {d }}$ data 'in the crowd.'

lohima-totalohima-totaalohima - to taa lohima-to ta lohima 'againts

the waiting guests'

- o-wo - liyo-lio

ambunguolio - ambunguwoliyo

ambunguoliyo - ambunguo liyo

'forgiven; be pardoned.'

- mayi, mota, mola, mao

lodelomayi-lodelomayi

lodelomai - lodelo mai

Consider the variation of $\mathrm{a}-\mathrm{w}$

delowamayi- delowa mayi

delowamai- delowa mai

deloamayi-deloa mayi

deloamai- deloa mai 'bring it here.'

delowamota - delowa mota 
16 | BAHASA DAN SENI, Tahun 46, Nomor 1, Februari 2018

deloamota - deloa mota

'bring it there' (near from here)

delowamola - delowa mola

deloamola - deloa mola

'bring it there (far from here)'

delowamao- delowa mao

delowama'o- delowa ma'o

deloamao- deloa mao

deloama'o- deloa ma'o

delowamaqo - delowa maqo

deloamaqo - deloa maqo

delowama?o - delowa ma?o

deloama?o - deloa ma?o

'bring it there (beside from here)'

- lo loheio-loheyio - lohei'o-loheyi'o 'invite'.

lohima - lo hima 'have been waiting.'

- malo sadiya - malo sadiya the term in

wombato malosadiya 'mats have been provided.'

- lio sahabati lio-sahabatilio

'Her/his friend/s'

keluarga lio-keluargalio 'her/his family/ies'

sisalio-sisalio 'tag end.'

- maqo tanggalepata

Tanggalepatamaqo, consider the

variation of $q-o-$ ' - ?

mao-maqo-ma'o- ma?o

tanggalepata $\underline{\text { maqo }}$ 
tanggalepatamao

tanggalepata $\underline{\boldsymbol{m a o}}$

tanggalepatama'o

tanggalepata $\underline{\mathbf{m a} \boldsymbol{\prime}}$

tanggalepatama?o

tanggalepata $\underline{\boldsymbol{m a} \boldsymbol{a} \boldsymbol{o}}$ 'moreover'

- lopo wonemo-lopo wonemo

Lopowonemo 'has given pleasure'

rasa-lopo rasa-loporasa 'has given sense'

- ta-taa lohulato-taalohulato- taa lohulato-

talohulato-ta lohulato

'who have been waiting'

- poto tala-taala poto taala - pototaala

Consider the variation of short vowel.

pototala - poto tala - pototala 'taking care of each other'

-ma-maa

$\boldsymbol{m a}$ lona'o - maa lona'o 'has gone' Consider the variation of $\boldsymbol{o}-\boldsymbol{q} \mathbf{-}^{`}-$ ?

malonao - maalonao

ma lonaqo - maa lonaqo

ma lona?o - maa lona?o

ma lona'o - maa lona'o

monao 'go'

mamonao - maamonao

ma monaqo - maa monaqo

ma mona?o - maa mona?o

ma mona'o - maa mona’o 'will go.'

There are 27 different variant forms of a word of its root ambungu 'forgive; sorry' that caused by the prefix $\boldsymbol{o}$ and suffix -wa; an attached it and the variation of both $\boldsymbol{o}-\boldsymbol{q}-$ '- ? Forms and long vowel of $\boldsymbol{a} \boldsymbol{a}$.

oambunguwa - o ambunguwa 
18 | BAHASA DAN SENI, Tahun 46, Nomor 1, Februari 2018

oqambunguwa - o qabunguwa

o’ambunguwa

o? ambunguwa - o ?ambunguwa

oambungu $\underline{\boldsymbol{a}}-\boldsymbol{o}$ ambungu $\underline{\boldsymbol{a}}-\boldsymbol{o q}$ ambungu $\boldsymbol{a}-\boldsymbol{o}$ qabungua

o? ambungua - o ?ambungua

oaambunguwa $-\boldsymbol{o}$ aambunguwa

oqaambunguwa -o qaambunguwa -o'aambunguwa

o? $\underline{a}$ ambunguwa $-\boldsymbol{o} ? \underline{a a}$ mbunguwa

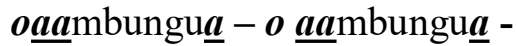

oqaambungua -o qaambungua

o’aambungua

o? $\underline{a a}$ mbungu $\boldsymbol{a}-\boldsymbol{o}$ ? $\underline{a} \underline{a}$ mbungu $\boldsymbol{a}$

'forgiven'.

It is considered that the variation of the word that has prefix po which is in its varying attach and non-attach it. It is possible to be 76 forms for the word $a m b u$ 'gather' with the prefixes po, $\boldsymbol{o}$ and the suffix $\boldsymbol{a}$ and $\boldsymbol{l a}$, i.e., oambuwa 'a place gather together'.

oambuwa - o ambuwa

oqambuwa - o qabuwa

o’ambuwa

o? ambuwa - o ?ambuwa

oambu $\underline{\boldsymbol{a}}-\boldsymbol{o}$ ambu $\underline{\boldsymbol{a}}-\boldsymbol{o q a m b u} \boldsymbol{a}-\boldsymbol{o}$ qabua

o? ambua - o ?ambua

oạmbuwa - o a a mbuwa

oqaambuwa -o qaambuwa-o'aambuwa

o? $\underline{a}$ mbuwa - o ?aambuwa

oaambua - o a a $\underline{\operatorname{ambu}} \underline{a}-$

oqaambua-o qaambua

o'aambua 
o? $\underline{a} \underline{a m b u} a-o$ ? $\underline{a a m b u} a$

poambuwa - poo ambuwa

pooqambuwa - poo qabuwa

poo'ambuwa

poo?ambuwa - poo ?ambuwa

pooambua - poo ambu $\underline{a}-$ pooqambua

poo qabua

poo?ambua - poo ?ambua

po oaambuwa - po o aambuwa

po oqaa mbunguwa - po o qaambuwa - po o'aambuwa

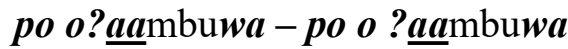

po oaambua - po o $\underline{\text { aa }}$ mbu $\underline{a}$ -

po oqaambua - po o qaambua

po o'aambua

po o? $\underline{a a}$ mbua - poo ? $\underline{a}$ mbua

po'oqambuwa - po'o qabuwa

po'o'ambuwa

po'o? ambuwa-po'o ?ambuwa

po'oambua - po'o ambua $\underline{\boldsymbol{a}}-\boldsymbol{p o}$ 'oqambua

po'o qabua

po'o? ambua - po'o ?ambua

po ?oaambuwa - po ?o aambuwa

po ?oqaambunguwa-po ?o qaambuwa - po ?o'aambuwa

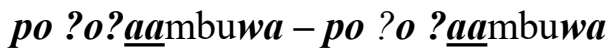

po ?oaambua - po ?o $\underline{\text { aambu}} \underline{a}$ -

po ?oqaambua-po ?o qaambua

po ?o'aambua 
20 | BAHASA DAN SENI, Tahun 46, Nomor 1, Februari 2018

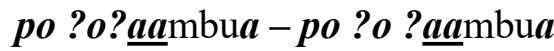

pooambuwala-po'o'ambuwala-poqoqambuwala-po?o?ambuwala

pooambuala-po'o'ambuala poqoqambuwala - po?o?ambuwala

\section{Varying Writing System of The Use of Long and Short Vowels in Gorontalo language.}

It has been stated that the previous mixing examples of varying forms of $\boldsymbol{o}-\boldsymbol{q}-\mathbf{-}-$ ?, long and short vowel, and stems or affixes attached and not attached to a word. Here, it is still given some examples of the problem of the varying system between the long and short vowels in Gorontalo language.

aa aadati -a'aadati- aqaadati-a? aadti 'with custom'

aadati - adati 'custom'

$\mathrm{d} a \boldsymbol{a} \mathrm{d} a \boldsymbol{a t a}-\mathrm{d} a \mathrm{~d} a \mathrm{ta}$

'many; much'

maayiloiya mayiloiya

maa yiloiya ma yiloiya

'already said'

Consider the varying form of the two forms of:

$\mathrm{i}$ - yi mailoia - ma yiloia

a - ya mailo'i $\boldsymbol{a}$ - ma yiloi' $\boldsymbol{a}$

taabiya-taabia 'miss each other.'

tabiya - tabia 'prayer'

mungkiriya- mungkiria 'deny it'

hihaadiriya- hihadiria-

hihadiriya 'being present'

sahaadati- sahadati-

syahaadati- syahadati

'shahadah; confession'

aaherati- aherati-aahirati-ahirati 'hereafter'

ii -i ilo tingiinga mola - ilo tinginga mola. Consider an affix attached and not attached to a word.

Ilotingingamola - ilotingiinga $\underline{\text { mola }}$ - ilotingingamola 'sounded; audible' 


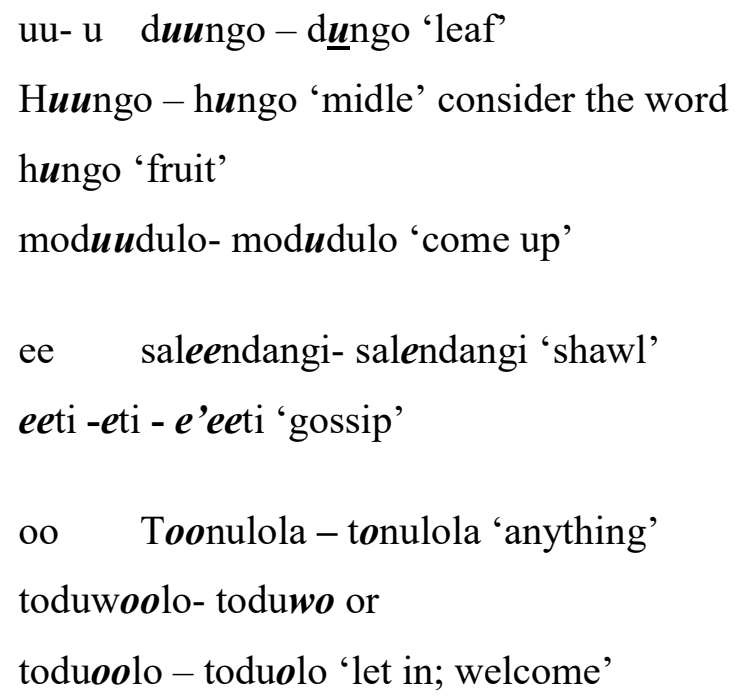

Synchronisation Agreement Results of Morphological and Phonological Varying Writing Word Forms

From these varying writing words forms of Gorontalo language, it can be accumulated that there are six essential parts which are needed to be considered and it is a must to look for the solution. One of the solutions has been done in relation to this study as one of the research programs is conducting a workshop on the $2^{\text {nd }}$ August 2017, followed by the community representatives from 5 (five) districts and one city of Gorontalo, included the special Guest Speaker in his major of Etno, Eco Linguistic, from Makassar, South Sulawesi, others attended with their cultural experts, linguistic experts in the area, and language and literary specialist. They were invited to present their proficiency and field qualification of their experience on culture and language in such a seminar, and then ended by the choosing alignments team to arrange in line with the using the standardization of beloved Gorontalo local language.

The agreement of the using Gorontalo language standardization is based on findings from organizing custom term Gorontalo language dictionary which have been presented in the previous varying problems of writing Gorontalo language word forms. The results of the agreement as the synchronization are illustrated as follows.

In morphological and phonological varying systems, the words are agreed upon on:

\section{1) The Variation of The Use of Vowel to Be Consonant in Each Word.}

It is synchronized by choosing the amount of words with its description below. ami $\underline{a t i} \underline{\boldsymbol{a}}$ ' we', there is no consonant ' $\boldsymbol{y}$ ' between $\boldsymbol{i}$ and $\boldsymbol{a}$. It only exists in it phonetic symbol /'ami' $\underline{\mathbf{a}}$ :'ti' $\mathbf{y}$ a/ others are as in:

utia /u'tiza/ 'this'. Not utiya

hunggi $\underline{a}$ /hungiza/ 'country; land' 
22 | BAHASA DAN SENI, Tahun 46, Nomor 1, Februari 2018

sadia /sa'dipa/ 'ready'

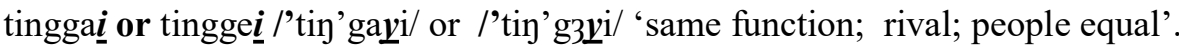

liodu /li'yodu/ 'step'

tiombu '/ti' $\mathbf{y}$ ombu/ 'grandmother/father'. Here, the letter $\boldsymbol{y}$ is a sound melted.

However, there are two sequence vowels written side by side in a row, and there is glottal sound, then it is written apostrophe between vowels i.e. $\boldsymbol{o}$ and $\boldsymbol{i}$, in lo' $i a$ /lo'iya/ 'speech'. Its special phonetic symbol of glottal is the same form as the morph. Moreover, not only the letter $\boldsymbol{y}$ is melted in certain Gorontalo language words, but also the letter $\boldsymbol{w}$. It happens in the words with its phonetic symbol as in:

wau/'wawu/ 'and'

$\operatorname{ta} \boldsymbol{u} /$ 'taw $\mathrm{u} /$ 'people'

bua /'buwa/ 'girl; woman'

moali /mo' wali/ 'can be'

pohutua/'pohu'tuwa/ 'do that'

toduoolo /'todu'wo:lo/

hilao/hi'lawo/ 'heart; wish'

Besides, there are words that have the same form but different meaning, this different meaning is logically considered because of minimal units of linguistics named phoneme. It is inserted with the apostrophe between the sequence of two vowels i.e., a, and $\boldsymbol{u}$, wa' $u$ and ta' $u$. Its special phonetic symbol of glottal is also the same form as the morphs, as in:

wa'u /'wau/ 'I'

ta'u/'tau/ 'above; over'

bu'a/'bua/ 'crack'

2) The Variation Changing the Vowels

$\mathbf{a}-\mathbf{u}$

b $\underline{a}$ nu /'bayu/ 'build' synchronized to be bongu/'boyu/ with the prefix mo in the word

momangu bele is to be momongu bele /mo'monu 'bele/ 'to build a house'

bangu /'bayu/ is synchronized to be mobangu /mo'bayu/ 'call to prayer'.

$\mathrm{u}-\mathrm{o}$

humolo is to be humulo /hu'mulo/ as in Bulentiti humulo /'bu'le:ntiti hu'mulo/ 'the exalted bride",

mo -ngo 
tapahumo to be tapahungo tapahungo lulungo /'tapa'huno lu'luuno/ 'corpse carried'.

wawu - wewu is the stem.

The word with this stem is chosen its word of otutuwawu lo Allah /o'tutu'wawu 'lo 'Allah/ 'the only one of Allah' not otutuwewu lo Allah. uwito is to be uito /u'yito/ 'that is'.

\section{Varying System of Writing Words Containing letters nt, nd, nth, and ndh.}

The choice is dominated by $\boldsymbol{n t}$ as in the following words hulontalo /'hulo'nðalo/ 'Gorontalo.'

pohuntala /'pohu'nðala/ 'serving delivery.'

huntingo /hu'nðino/ 'cutting; scissor'

Ilohuntuwa /'ilohu'nðuwa/ 'a gathering place.'

huhuntula /'huhu'nðula/ 'employees; the welcome guests'

pontolo /po'nðolo/ 'border'

pohintu/pohinðu/ 'ask for permission; agreement'

The Stems or Particles Which Are Chosen Are: to (with the noun), ta, liyo;lio, o, lo, ma, mao;maqo, mota, mola, mayi;mai).

Those forms are not attached to a word. These are as in the following words. to-to ta

to dala /'to 'dala/ ' on the street'

to pomama /'to po'mama/ 'in place of a set of siri tools'.

to tahua /'to 'ta:'huwa/ 'in a storange' to $\underline{\text { ta }}$ d $\underline{\text { a }}$ data /'to 'ta: da'da:ta' 'in the crowd'

to ta lohima /'to 'ta: lo'hima/ 'againts the waiting guests'

ta lohulato /ta: 'lohu'lato/ 'who have been waiting'

the suffix liyo to be lio is attached to the root as in ambunguolio /a:'mbunu'wo'lio/

'forgiven; be pardoned'

o wuhua /'o wu'huwa/ 'expelled'

lo $\underline{\boldsymbol{l}} \boldsymbol{\mathrm { ohe }}$ 'o /'lohe'yio/ 'invite'is chosen from the other forms of loheio-lo heyio- loheyi'o.

lohima /lo'hima/ is chosen from the form of lo hima 'have been waiting'.

ma $\boldsymbol{m a}$ toduoolo /'ma: 'todu'wolo/ is chosen the forms of $\boldsymbol{m a t o d u w o o l o ~ a n d ~ m a t o d u w o l o ~}$

'welcome'.

Using mayi, mota, mola,mao

lodelo mai /lo'delo'mayi/

deloa mai 'bring it here' 
24 | BAHASA DAN SENI, Tahun 46, Nomor 1, Februari 2018

deloa mota /lo'delo'mota/ 'bring it there' (near from here)

deloa mola /lo'delo'mola/ 'bring it there (far from here)'

deloa ma'o /lo'delo'ma'o/ 'bring it there (beside from here)'

In principle, the use of mayi, mota, mola, mao are not attached to the root or verb. malo is used separately from the root, or it is attached or not attached to the root sadiya malo sadiya the term in wumbato ma losadia /wu'mbato ma: losa'diya/ 'mats have provided'. wumbato malo sadia /wu'mbato 'malo sa'diya/ 'mats have been provided'.

$\underline{\boldsymbol{m a}}$ lohuhulo "had cooled, became cold

$\underline{\text { malo }}$ huhulo 'really cold

liyo-lio sahabatilio 'her/his friend/s'

keluargalio 'her/his family/ies'

sisalio 'tag end'. Those are attached

to the root and those forms are chosen.

maqo tanggalepata

tanggalepata $\underline{\boldsymbol{m a} \boldsymbol{\prime} \boldsymbol{0}}$ is the form

chosen from the others which

have varying forms of mao-maqo-ma'o- $\boldsymbol{m a} \boldsymbol{a} \boldsymbol{o}$ as bellow.

tanggalepata $\underline{\text { maqo }}$

tanggalepatamao

tanggalepata $\underline{\text { mao }}$

tanggalepatama'o

tanggalepatama?o

tanggalepata $\underline{\boldsymbol{m a} \boldsymbol{a} \boldsymbol{o}}$ 'moreover'

Lopowonemo 'has given pleasure' It is chosen than the other of

Lopo wonemo. It also happens on loporasa 'has given sense' is chosen from lo porasa. poto pototala 'taking care of each other' is the choice from other that not attached the root, as in both words below.

ma-maa

ma lona'o 'go' 
ma mona'o 'will go'

The words $o$ ambungu $a$ (the meaning of reference is in singular concept) and $\boldsymbol{o}$ $\underline{\boldsymbol{a} a m b u n g u \boldsymbol{a}}$ (the meaning of reference is in plural concept) are the choice words from the twenty seven different varying forms of ambungu 'forgive; sorry' word or root. Those variations are caused by the prefix $\boldsymbol{o}$ and suffix $-\boldsymbol{w a}$; $\boldsymbol{a n}$ attached it and the variation of both $\boldsymbol{o}-\boldsymbol{q}$ - '- ? Forms and a long vowel in Gorontalo language.

\section{Varying Writing of The Use of The Three Main Forms of a -q-'-? long and short} vowel, and stems or affixes attached and not attached to a word in Gorontalo language.

The combination of the three varying forms can be seen in the following workshop results agreement. Those words have been chosen from each of their group of the word. Those are presented as below.

-aa a'aadati 'solidified' is chosen from $\boldsymbol{a} \boldsymbol{a}$ dati-a'adati -a'aadati-aqaadati a?aadti

aadati 'custom' is chosen from adati.

$\mathrm{d} \boldsymbol{a} \mathrm{d} \boldsymbol{a} \boldsymbol{a t a}$ 'many/much' is chosen from the form of daadaata.

baate 'custom leader' is chosen from bate;

bate is the choice for the meaning of 'batik'.

maama 'mother' is chosen from mama.

mama is the choice for the 'set of sirih/betel tool'.

The long vowel aa /a: / in a'aadati, aadati, baate, maama is a phoneme that makes different meaning between their group of the word.

ma yilo'ia 'already said is chosen from others' form of maayiloiya - maa yiloiya - ma yiloiya.

$\boldsymbol{m a}$ lo'i-lo'ia 'is being speaking' is the choice

Consider the varying form of the two forms of:

taabia 'miss each other' is chosen/agreed from taabiya

tabia 'prayer' is chosen from tabiya.

mungkiria 'deny it' is agreed from mungkiriya .

hi hadiria is chosen from hihaadiriya, hihadiria, and hihadiriya 'being present'

sahaadati is chosen from sahadati, syahaadati, and syahadati

'shahadah; confession'.

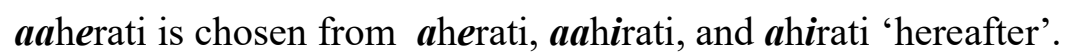


pa'ia lo hungo lo poli 'mutual reply rhymes' is chosen from paiya lo hungo lo poli, paaiya lohungo lopoli, paa'ia lo hungo lo poli.

tiinti bolu is chosen from tinnti bolu, tinnthi bolu, and ti ndhi bolu.

-ii -i ilotiinga mola 'sounded; audible' is chosen from ilo tinga mola, ilotingamola,

ilotiinga mola, and ilotingamola.

piilu is chosen from pilu.

- uu- u duungo 'leaf' is chosen from dungo.

Consider the same of each two words below;

huungo 'middle' is chosen from hungo.

hungo 'fruit' is chosen from huungo and hungo

moduudulo 'approaching; comes up' is chosen from modudulo.

modudulo 'like to approach' is chosen from moduudulo.

podulualo 'defended' is chosen from po dulualo, and poduluwalo.

-ee saleendangi 'shawl' is chosen form salendangi.

$\boldsymbol{e}$ 'eeti 'gossip' is chosen from eeti and $\boldsymbol{e}$ ti.

-oo toonulola 'anything' is chosen from tonulola.

toduoolo 'let in; welcome' is chosen from toduwoolo, toduwolo, and toduolo.

ti' ayo 'invite' is chosen from tiayo, tiao, and ti'ao.

\section{The Varying Writing Forms and The Infix.}

The variation of the word that has prefix po with the varying combination of the three main forms in the previous number 5 above, it might be possible to be more word forms of 72 , i.e the word ambu 'gather'. From the amount of these words variation, some of them have been agreed in the workshop result synchronization. They are:

o'ambuwa 'association',

po'ambua 'command to assemble',

ngo po'ambua 'one association',

po'aambua 'command to assemble to many people',

popo'aambua 'collect please',

mo'ambua 'get together',

mopo'ambua 'trying to get together',

po'o'ambuala 'a gathering place; the place where to gather'. 
Other words that are from the term dictionary have been considered to be synchronized are as follows

hiyo has to be hio

totaowa- totayoa has to be totayoa

o'ayuwa_has to be o'ayua

pohuwa has to be pohua

o'oliyo'o has to be o'olio'o

pu'owa has to be pu'oa

popo dapata_has to be popodapata

buwata has to be buata

buwatulo aadati - buatulo adati has to be buatulo aadati

de uyito - de'uito - de'uyito has to be de uito

diipo leehuloqo - dipolehulo'o has to be dipo lehulo'o

delowa has to be deloa

mowali has to be moali

diyalu - dialu has to be diaalu

diyamba has to be diamba

hiambuwa-hi'ambua has to be hi ambua

huliya has to be hulia

lopowameto has to be lopohemeto

$\boldsymbol{o}$ buto'a has to be obuto'a

$\boldsymbol{o}$ data - odata - o daata has to be odaata

to tahuwa - to tahua - to taahuwa - has to be

\section{to taahua}

tapahula lo huwa has to be tapahula lo hua

tiyombu ti'uwa has to be tiombu ti'ua

tuwoto has to be tuoto

o uaalo - o u'aalo has to be o u'alo

\section{CONCLUSION}

In line with the effort of finding the problem of the non-standardization of Gorontalo language in the draft of custom term dictionary and by the alignment team to synchronize

writing form of words, there are the results mutually agreed by the alignment team in front 
of society and the government representative on the workshop. This result can be the government policy to establish the certainty of standardization of Gorontalo language.

Standardization agreement from this activity found from all words that have been chosen in each point of the previous six illustrations. These are accumulated here. The accumulation are i) melting sound $\boldsymbol{y}$ and $\boldsymbol{w}$ in certain words, ii) there is special phonetic symbol of apostrophe to glottal sound between two sequence vowels written side by side in a row, iii) choosing letters $n t$ to its sound of $\circlearrowright$, iv) choosing not attached to a word of particles mayi, mota, mola, ma, ngo, o (for verb not for noun), hi, lo, de, dipo, ta, v) choosing attaching prefix po to verbs, vi) varying writing the use long and short vowels in terms the phonemes to make the different meaning.

For the future activity of systematizing the standardization custom term dictionary, it is not only so possible to organize this dictionary in term of avoiding far from the problems of repeating the same term in different pages and spaces in dictionary, but also avoiding the two possible definitions of one word or term which may effect of making different formulation or description of sentences in defining the term.

It is suggested that all Gorontalo societies and the governments who are aware of their varying language form of writing words that now has been synchronized may use or apply this standardization.

\section{REFERENCE}

Akbulut, Fatma Demiray. 2017. Effects of Morpholgical Awareness on Second Language Vocabulary Knowledge. Journal of Language and Linguistic Studies. 13(1), 10-26; 2017/JLLS and Authors.

Chaer, Abdul. 2009. Pengantar Semantik Bahasa Indonesia. Jakarta: Rineka Cipta

-------. 2007. Leksikologi \& Leksikografi Indonesia. Jakarta: PenerbitRineka Cipta.

Cristal, David. 1985. A Dictionary of Linguistics and Phonetics. Oxford: Basil Blackwell, Ltd

Djayasudarma, T. Fatimah. 2008. Semantik I. Pengantar ke Arah Ilmu Makn. Pengantar ke Arah Ilmu Makna. Bandung: Refika Aditama.

Kemeny, J., G., \& Thomas, E. K. 1985. True basic, the structured language system for the

Future. reference manual. USA: Addison - Wesley Publishing Company, Inc.

Lardiere, Dona. 2006. "Words and Their Parts".Ralph Fasold and Jeff Connor-Linton (Eds). An Introduction to Language and Linguistics. P.55-96. Cambridge: Cambridge University Press.

Roach, Peter. 2000. English Phonetics and Phonology.A Practical Course. $3^{\text {rd }}$. Cambridge: Cambridge University Press.

Ulman, Stephen. 1977. Pengantar Semantik. Terjemahan oleh Sumarsono. Yogyakarta: Pustaka Pelajar.

Zsiga, Elisabeth. 2006. "The Sounds of Language". Ralph Fasold and Jeff Connor-Linton (Eds).An Introduction to Language and Linguistics, p. 13-53. Cambridge: Cambridge University Press.

Springer, Definition and Golds of Descriptive Linguistic Fieldwork https://www.google.co.id/search?q=liguistic + descriptive + pdf\&oq=liguistic + descriptive + pdf\&aqs $=$ chrome..69i57j0.13175j0j7\&sourceid $=$ chrome\&ie $=U T F-8$

http://www.ling.upenn.edu/ rnoyer/courses/51/Ling512011Morph.pdf Linguistics 051 Proto-Indo-European Language and Society Introduction to Morphology 